\title{
Sintesis Kulit Ubi Kayu (manihot esculenta) Sebagai Bahan Dasar Pembuatan Kemasan Biodegradable
}

\section{Synthesis of Cassava Bark (manihot esculenta) As a Basic Material for Making Biodegradable Packaging}

\author{
Adil, Program Studi Pendidikan Teknologi Pertanian, Universitas Negeri \\ Makassar. Email: adil10mhagmail.com \\ Patang, Program Studi Pendidikan Teknologi Pertanian, Universitas Negeri \\ Makassar. Email: patang@unm.ac.id \\ Andi Sukainah, Program Studi Pendidikan Teknologi Pertanian, Universitas Negeri \\ Makassar. Email: andisukainah@yahoo.com
}

\begin{abstract}
Abstrak
Penelitian bertujuan untuk mengetahui pengaruh variasi konsentrasi pati terhadap karakteristik film biodegradable dari pati kulit ubi kayu. Penelitian ini merupakan (RAL) yang terdiri dari 3 perlakuan menggunakan bahan utama gliserol dan kitosan (1:3) dengan penambahan konsentrasi pati 45\%, 50\% dan 55\%. dan 3 kali ulangan. Variable yang diamati adalah uji kuat tarik, uji persen perpanjangan, uji ketahanan air dan uji biodegradibilitas. Teknik analisis yang digunakan dalam penelitian ini adalah analisis sidik ragam yang diolah dengan menggunakan SPSS versi 20. Hasil penelitian menunjukan penambahan konsentrasi pati kulit ubi kayu (Manihot esculenta) berpengaruh secara signifikan terhadap uji yang meliputi karakteristik kuat tarik, persen perpanjangan, ketahanan air dan biodegradibilitas dimana pembuatan kemasan biodegaradable. Untuk parameter kuat tarik, ketahanan air dan biodegradibilitas perlakuan terbaik terdapat pada penambahan konsentrasi pati kulit ubi kayu 55\% sedangkan pada uji perpanjangan perlakuan terbaik pada konsentrasi pati kulit ubi kayu 50\%.
\end{abstract}

Kata Kunci: Biodegradable, Kemasan, Kulit Ubi Kayu, Sintesis

\begin{abstract}
The study aims to determine the effect of variations in starch concentration on the characteristics of biodegradable films from cassava starch. This research is a RAL consisting of 3 treatments using the main ingredients glycerol and chitosan (1:3) with the addition of starch concentrations of 45\%, 50\% and 55\%. and 3 replications. The observed variables are tensile strength test, percent extension test, water resistance test and biodegradiability test. The analysis technique used in this study was analysis of variance which was processed using SPSS version 20. The results showed that the addition of cassava skin starch concentration (Manihot esculenta) significantly affected the test which included tensile strength characteristics, elongation percent, water resistance and biodegradiability where making biodegaradable packaging. For the parameters of tensile strength, water resistance and biodegradiability of the best treatment there is an increase in the concentration of cassava skin starch 55\%, while in the extension of the best treatment at 50\% cassava skin starch concentration.
\end{abstract}

Keywords: Biodegradable, Packaging, Cassava Skin, Synthesis 


\section{Latar Belakang}

Kemasan plastik merupakan wadah atau tempat untuk memberikan perlindungan sesuai tujuannya. Penggunaan plastik sebagai kemasan karena memiliki kelebihan antara lain bersifat kuat, ringan, fleksibel, tahan lama dan murah. Selain kelebihan yang sangat bermanfaat plastik kemasan menimbulkan permasalahan bagi lingkungan. Sampah yang dihasilkan oleh plastik kemasan sulit terdegradasi atau tidak dapat diuraikan secara alami oleh mikroba di dalam tanah, sehingga terjadi penumpukan sampah plastik yang dapat menyebabkan pencemaran dan kerusakan bagi lingkungan. Kelemahan lain adalah bahan utama pembuat plastik yang berasal dari minyak bumi, yang keberadaannya semakin menipis dan tidak dapat diperbaharui.

Sampah plastik kemasan yang sulit terdegradasi mendorong banyak pihak untuk melakukan penelitian membuat plastik kemasan yang mudah terdegradasi. Salah satu cara yang dapat dilakukan untuk mengurangi permasalahan lingkungan tersebut yaitu mengembangkan biodegradable. Seiring dengan persoalan ini, maka penelitian bahan kemasan diarahkan pada bahan-bahan organik yang dapat dihancurkan secara alami dan yang paling penting bahannya mudah diperoleh.

Biodegradable merupakan plastik yang berasal dari bahan alam dan dapat diuraikan oleh mikroorganisme menjadi senyawa yang lebih sederhana. Bahanbahan yang dapat digunakan salah satunya pati.Pada penelitian ini adalah pati kulit ubi kayu jenis adira 1 karena memiliki Kandungan pati berkisar 44-59\% dan yang paling tinggi diantara semua jenis ubi kayu. Ketersedian ubi kayu di Indonesia cukup tinggi berdasarkan data Badan Pusat Statistik tahun 2005, luas areal pertanaman ubi kayu di Provinsi Sulawesi Barat mencapai $14.820 \mathrm{Ha}$ dengan total produksi 1.207,36 ton. Areal tersebut terdapat di Kabupaten Polewali Mandar seluas 4.680 Ha dengan produksi sebesar 211,66 ton, Kabupaten Majene 114,14 ton dengan luas $3.696 \mathrm{Ha}$, Tinambung 136,41 ton dengan luas 605 ha, Pambusuang 53,34 ton dengan luas 754 ha.Produksi ubi kayu yang melimpah tentunya menyisahkan permasalahan lingkungan berupa kulit ubi kayu. Kulit ubi kayu mencapai 10-20\% dari umbidan lapisan periderm mencapai 0,5$2,0 \%$ dari total berat umbi, lapisan korteks yang berwarna putih mencapai $8-19,5 \%$. Berdasarkan penelitian pendahuluan Lazuardi (2013) menyatakan dalam $100 \mathrm{~g}$ kulit ubi kayu mengandung pati 15-20 g.

Plastik biodegradable memiliki peluang usaha yang besar di Indonesia karena pemerintah pernah menyuarakan tentang sampah plastik yang ada di Indonesia. Biodegradable dengan kegunaan dan fungsi hampir sama dengan plastik yang terbuat dari minyak bumi akan sangat diminati oleh pemerintah kemudian akan menjadi prioritas utama pemerintah untuk diproduksi di Indonesia karena kelebihan dari plastik biodegradable ini mudah terurai.

Kandungan pati yang berasal dari kulit ubi kayu yang cukup tinggi memungkinkan digunakan sebagai film plastik biodegradabel. Potensi tersebut dapat digunakan sebagai peluang untuk memberikan nilai tambah pada kulit ubi kayu sebagai bahan dasar dalam pembuatan kemasan plastik yang ramah lingkungan. Pada penelitian ini pati yang digunakan adalah pati yang berasal dari kulit ubi kayu adera 1 , namun dalam penggunaan pati ubi kayu masih memiliki kekurangan yaitu mudah sobek maka dilakukan penambahan film dengan bahan kitosan yang 
mempunyaisifat komponen reaktif, pengikat, pengkilat, pengabsorbsi, penstabil, pembentuk film (yang mudah di biodegradabillity) sedangkan film berbahan gliserol memiliki kemampuan membentuk lapisan film (yang fleksibilitas).

Penambahan kitosan untuk menghasilkan sifat mekanik yang baik telah dilakukan Aripin (2017) yang meneliti studi pembuatan bahan alternatif Plastik biodegradable dari pati ubi jalar dengan plastcizer glizerol dengan metode melt intercalation. Penambahan kitosan yangmemiliki struktur rantai polimer dan cenderung membentuk fasa kristalin akanmeningkatkan kekuatan bioplastik.

Penambahan gliserol pada pembuatan bioplastik telah dilakukan Arisma (2017) yang meneliti pengaruh penambahan plasticizer gliserol terhadap karakteristik edible film dari pati talas (Colocasia esculenta L. schott).

Berdasarkan uji kesukaan yang dilakukan pada 30 orang mahasiswa menunjukkan bahwa konsumen menyukai dodol yang dikemas menggunakan edible film dengan konsentrasi gliserol 30\%, baik dari segi warna, aroma, rasa dan kekenyalan.

Berdasarkan uraian di atas penelitian ini berupaya membuat biodegradabledari pati kulit ubi kayu (Manihot esculenta) dengan berbagai variasi konsentrasi pati (45\%, 50\% dan 55\%) dengan bahan utama menggunakan kitosan dan gliserol. Adapun konsentrasi gliserol dan kitosan (1:3) sebagai perlakuan control ini sesuai dengan penelitian Selpiana (2016) yang memiliki perlakuan (Gliserol:Kitosan) terbaik pada 1:3. Variasi konsentrasi pati bertujuan untuk mengetahui konsentrasi optimum terhadap karakteristik film biodegradable yang dihasilkan. Selanjutnya film biodegradable tersebut diuji karakteristiknya dengan parameter uji ketahanan air dan uji biodegradibiltas. Untuk membantu mengetahui hasil analisis uji karakteristik biodegradable yang diperoleh berpengaruh secara signifikan atau tidaksignifikan, dilakukan analisis menggunakan SPSS (Statistical Package for Social Science) versi 20.0.

Adapun tujuan dalam Penelitian ini adalah untuk mengetahui pengaruh variasi konsentrasi pati terhadap karakteristik film biodegradable dari pati kulit ubi kayu (Manihot esculenta).

\section{Bahan dan Metode}

Penelitian adalah penelitian eksperimen, dimana peneliti menggunakan rancangan acak lengkap (RAL). Rancangan acak lengkap dapat didefinisikan sebagai rancangan dengan beberapa perlakuan yang disusun secara random untuk seluruh unit percobaan. Desain ini digunakan karena percobaan dilakukan dilaboratorium dan kondisi lingkungan dapat dikontrol (Nazir, 2003). Desain penelitian dengan 4 perlakuan dan kontrol sebagai pembanding. Perlakuan A: gliserol - Kitosan 1:3 dengan penambahan Pati 45\%, Perlakuan B: gliserol - Kitosan 1:3 dengan penambahan Pati 50\%, Perlakuan C: gliserol - Kitosan 1:3 dengan penambahan Pati 55\% serta kontrol tanpa penambahan pati.

\section{Waktu dan Tempat}

Penelitian ini dilaksanakan di Laboratorium Pendidikan Teknologi Pertanian, Laboratorium Kimia Analitik Universitas Islam Negeri Alauddin Makassar dan Laboratorium Fisika Balai Besar Industri Hasil Perkebunan. Waktu pelaksanaan penelitian dimulai Pada bulan Februari-April 2019. 


\begin{abstract}
Alat dan Bahan
Peralatan yang digunakan yaitu oven digital, neraca analitik, mechanical universal testing machine, gelas ukur 100 $\mathrm{ml}$, thermometer $110{ }^{\circ} \mathrm{C}$, gelas kimia 250 $\mathrm{ml}$, pipet skala $1 \mathrm{ml}$, cetakan kaca ukuran 20 × $20 \mathrm{~cm}$, wadah larutan, wadah kedap udara, blender, spatula dan gunting. Sedangkan bahan yang digunakan yaitu pati kulit ubi kayu (Pati), aquadest $\left(\mathrm{H}_{2} \mathrm{O}\right)$, gliserol, kitosan, natrium klorida, asam asetat dan Lampu.
\end{abstract}

\section{Tahap Persiapan}

\section{Pembuatan Larutan Pati}

Larutan pati dibuat dengan cara menimbang pati kulit ubi kayu dengan berat $2 \mathrm{~g}$ dilarutkan dalam $100 \mathrm{ml}$ aquades di dalam gelas kimia, kemudian diaduk selama 25 menit dengan cara pemanasan di atas kompor listrik pada suhu $80^{\circ} \mathrm{C}$ sampai terbentuk larutan homogen. Perlakuan pembuatan larutan pati diulangi untuk perlakuan B dan perlakuan C serta ulangan.

\section{Pembuatan Larutan Kitosan}

Larutan kitosan dibuat dengan cara menimbang kitosan dengan berat $2 \mathrm{~g}$ dilarutkan dalam $100 \mathrm{ml}$ aquades di dalam gelas kimia $250 \mathrm{ml}$. Selanjutnya dilarutkan dalam asam asetat $1 \%$, kemudian diaduk selama 25 menit dengan cara pemanasan diatas kompor listrik pada suhu $85^{\circ} \mathrm{C}$ sampai terbentuk larutan homogen dan membentuk larutan kental.

\section{Pembuatan Biodegradable}

Pembuatan biodegadable dilakukan dengan cara mencampurkan larutan gliserol dan kitosan dengan larutan pati sesuai perlakuan $(1: 3+45 \%)$. Setelah itu, larutan biodegadable dihomogenkan diatas hot plate pada suhu $85^{\circ} \mathrm{C}$ selama 25 menit. Perlakuan diulangi pada masing-masing variasi perlakuan pati (50\% dan 55\%) serta kontrol (tanpa penambahan pati) untuk mengetahui pengaruh penambahan pati terhadap biodegadable dan dilakukan sebanyak tiga kali.

Larutan tersebut dituang ke dalam cetakan kaca ukuran $20 \mathrm{~cm}$ x $20 \mathrm{~cm}$. Cetakan yang berisi larutan film kemudian dikeringkan pada suhu $60^{\circ} \mathrm{C}$ selama 24 jam. Cetakan dikeluarkan dari oven dan didinginkan pada suhu kamar selama 10 menit. Film yang terbentuk dikelupas (peeling) dengan bantuan larutan $\mathrm{NaOH} 4 \%$ sampai larutan biodegadable terlepas dari cetakan. Berdasarkan hasil penelitian larutan biodegadble dapat terlepas dari cetakan selama 30 menit. Larutan $\mathrm{NaOH}$ berfungsi sebagai larutan non pelarut yang dapat berdifusi kebawah lapisan biodegadable sehingga biodegadable terangkat keatas dan mudah dilepas (Santoso,2006). Film yang diperoleh diuji ketahanan air dan uji biodegadibilitas.

\section{Hasil dan Pembahasan}

Data dalam penelitian ini diperoleh dari hasil uji sifat mekanik biodegradable dan pengujian uji biodegradibilitas. Pengujian sifat mekanik biodegradable yang dilakukan yaitu dengan menggunakan metode melt intercalation. Uji sifat mekanik biodegradable meliputi, uji kuat tarik, uji persen perpanjangan dan uji ketahanan air. Uji ini dilakukan untuk mengetahui plastik biodegradable berbahan dasar pati digunakan sebagai bahan dasar pembuatan kemasan biodegradable, serta uji biodegradibilitas untuk mengetahui berapa lama kemasan biodegradable sampai terdegradasi sempurna dapat dilihat pada table 1 . 
Tabel 1. Hasil Pengukuran Uji Sifat Mekanik

\begin{tabular}{cccc}
$\begin{array}{c}\text { Karakteristik } \\
\text { Biodegradable }\end{array}$ & $\begin{array}{c}\text { Konsentrasi Pati } \\
(\boldsymbol{\%})\end{array}$ & Nilai Rata-Rata & $\begin{array}{c}\text { Standar } \\
\text { Biodegradable }\end{array}$ \\
\hline Kuat Tarik (MPa) & 45 & $25.57 \pm 20.94$ & \\
& 50 & $31.84 \pm 30.40$ & $24,7-302(\mathrm{SNI})$ \\
Persen Perpanjangan (\%) & 55 & $73.97 \pm 65.10$ & \\
& 45 & $125.4 \pm 15.56$ & \\
Ketahanan Air (\%) & 50 & $126.1 \pm 12.76$ & $21-220(\mathrm{SNI})$ \\
& 55 & $103.9 \pm 55.04$ & \\
Biodegradibilitas $(\%)$ & 45 & $31 \pm 21$ & \\
& 50 & $36 \pm 43$ & \\
& 55 & $50 \pm 84$ & - \\
\end{tabular}

\section{Uji Kuat Tarik (SNI 24,7-302MPa)}

Kuat tarik adalah gaya tarik maksimum yang dapat ditahan oleh lembaran plastik selama pengukuran berlansung. Kekuatan maksimum yang dimaksud merupakan tegangan maksimum yang dapat dicapai pada diagram tegangan suatu regangan dapat dilihat pada Gambar 1. berikut:

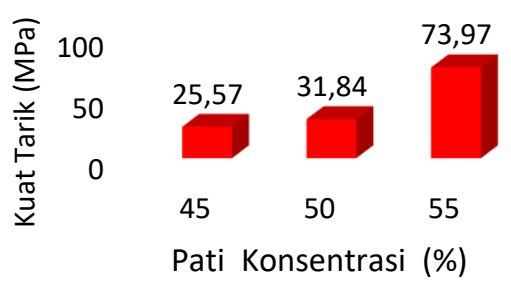

\section{Gambar 1. Pengaruh Penambahan Konsentrasi Pati Terhadap Uji Kuat Tarik Biodegradable}

Hasil analisis terhadap uji kuat tarik yang dihasilkan pada Gambar 1 menunjukan kuat tarik pada masing-masing perlakuan signifikan. Pada perlakuan kontrol tidak dilakukan uji kuat tarik karena dalam proses pengelupasan film biodegradable tidak terbentuk. Pada perlakuan pati $45 \%$ diperoleh kuat tarik paling rendah yaitu $25,57 \mathrm{MPa}$ dan setiap konsentrasi mengalami kenaikan yang signifikan. Pada konsentrasi pati $50 \%$ dengan nilai rata-rata sebanyak $31,84 \mathrm{MPa}$, merujuk pada SNI bioplastik yaitu sebesar 24,7-302 MPa maka konsentrasi 45\% dan $50 \%$ memenuhi standard SNI, sedangkan tingkat kuat tarik paling tinggi pada konsentrasi pati $55 \%$ dengan nilai rata-rata 73,97MPa. Pada konsentrasi 55\% memiliki konsentrasi pati terbaik yang paling mendekati nilai maksimal SNI.

Perlakuan konsentrasi pati $45 \%$ dengan memiliki nilai rata-rata $25,57 \mathrm{MPa}$ menunjukan nilai kuat tarik yang paling rendah diantara semua perlakuan. Ini dikarenakan sedikitnya ikatan dari pati yang dapat berikatan dengan kitosan dan gliserol sehingga menyebabkan kuat tarik film biodegradable semakin rendah (Anita, 2013). Pada perlakuan konsentrasi pati $55 \%$ dengan nilai rata-rata $73,97 \mathrm{MPa}$ menunjukan nilai kuat tarik yang mendekati nilai maksimal dari SNI biodegradable sehingga pada perlakuan konsentrasi pati 55\% merupakan nilai kuat tarik terbaik diantara semua konsentrasi perlakuan.

Hasil penelitian pada penambahan konsentrasi pati 55\% menunjukan kuat tarik paling tinggi dan pada perlakuan kontrol 
tidak terbentuk film. Hal ini dikarenakan pati sebagai pembentuk film biodegradable sehingga semakin tinggi konsentrasi pati yang diberikan maka berpengaruh terhadap film kuat tarik. Pada perlakuan konsentrasi $55 \%$ mengalami kenaikan yang signifikan dengan nilai rata-rata $73,97 \mathrm{MPa}$ melebihi SNI biodegaradable, ini dikarenakan perbandingan antara gliserol, kitosan dan pati sangat berpengaruh. Salah satu penyebab perbedaan yang signifikan terhadap penambahan konsentrasi pati pada kuat tarik adalah penggunaan waktu dan suhu pengadukan sehingga larutan biodegradable mengalami geletanisasi. Suhu pemanasan yang digunakan suhu $85^{\circ} \mathrm{C}$ selama 25 menit. Menurut Wutoy (2013) bahwa suhu tersebut merupakan suhu gelatinasi yang baik. Pemanasan 25 menit terjadi gelatinasi sempurna pada larutan pati, viskometer suhu gelatinisasi dapat ditentukan, misalnya pada jagung $62-70{ }^{\circ} \mathrm{C}$, kentang $58-66^{\circ} \mathrm{C}$ dan Ubi jalar $80-90^{\circ} \mathrm{C}$ (Winarno, 2002). Penggunaan suhu dan waktu yang tetap namun konsentrasi pati dinaikkan sehingga menyebabkan geletanisasi pati akan menyebabkan pasta pati menjadi sangat kental.

\section{Uji Persen Perpanjangan (SNI 21-220\%)}

Persen perpanjangan merupakan panjang putus (elongation at break) atau perubahan panjang maksimum pada saat terjadi peregangan hingga sampel film terputus dapat dilihat pada Gambar 2 berikut:

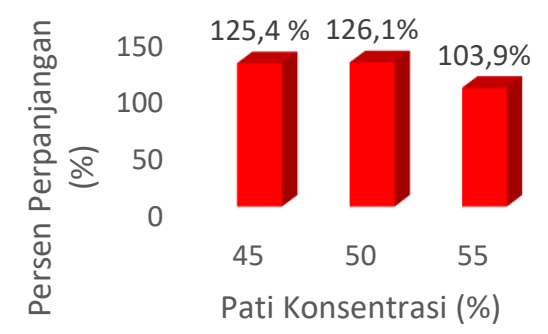

Gambar 2. Pengaruh Penambahan Konsentrasi Pati Terhadap Uji Persen Perpanjangan Biodegradable
Hasil analisis terhadap uji persen perpanjangan yang dihasilkan pada Gambar 2 menunjukan persen perpanjangan pada masing-masing perlakuan yang signifikan. Pada perlakuan kontrol tidak dilakukan uji persen perpanjangan karena dalam proses pengelupasan film biodegradable pada perlakuan kontrol tidak terbentuk. Hasil analisis terhadap uji persen perpanjangan yang diperoleh nilai rata-rata yang berbanding terbalik dengan nilai kuat tarik. Pada perlakuan pati $45 \%$ diperoleh persen perpanjangan paling rendah yaitu $103,9 \%$. Pada konsentrasi pati $50 \%$ dengan nilai rata-rata sebanyak $126,1 \%$, jika merujuk pada SNI bioplastik yaitu sebesar 21-220\%, maka konsentrasi $45 \%$, 50\% dan 55\% memenuhi SNI biodegradable. Tingkat persen perpanjangan paling rendah pada konsentrasi pati 55\% dengan nilai rata-rata 103,9\%. Perlakuan konsentrasi terbaik pada uji persen perpanjangan berdasarkan SNI yakni pada pati konsentrasi 50\%.

Pada perlakuan konsentrasi pati $45 \%$ dengan nilai rata-rata $125,4 \%$ menunjukan nilai persen perpanjangan tertinggi kedua. Ini dikarenakan sedikitnya ikatan dari pati yang dapat diikat oleh kitosan dan gliserol sehingga menyebabkan keadaan persen perpanjangan film biodegradable semakin rendah. Pada perlakuan konsentrasi pati 55\% dengan nilai rata-rata $103,9 \%$ menunjukan paling rendah diantara semua perlakuan. Jika merujuk pada SNI biodegradable sehingga pada perlakuan konsentrasi pati $50 \%$ merupakan nilai kuat tarik terbaik diantara semua perlakuan. Semakin tinggi konsentrasi pati yang ditambahkan maka semakin tinggi kuat tarik yang dihasilkan dan semakin tinggi nilai kuat tarik biodegradable maka nilai perpanjangannya akan semakin rendah. Ini dikarenakan banyak ikatan yang dapat terikat oleh gliserol dan kitosan yang menyebabkan ikatan hidrogen semakin rapat dan kaku 
sehingga film biodegradable sulit untuk ditarik dan perpanjangannya akan semakin rendah.

$$
\text { Nilai persen perpanjangan }
$$
konsentrasi terbaik yang diperoleh pada penelitian ini yaitu dengan nilai rata-rata $126,1 \%$, hasil yang diperoleh berbeda jauh dengan hasil yang diperoleh peneliti terdahulu yaitu dengan nilai persen perpanjangan $2,78 \%$ untuk bioplastik ampas tebu dan ampas tahu dengan penambahan kitosan dan gliserol (Selpiana, 2016). Film dengan persen perpanjangan tinggi menunjukkan bahwa pati kulit ubi kayu masuk dalam kategori bahan dasar yang bisa dijadikan sebagai plastik biodegradable.

\section{Uji Ketahanan Air (SNI 99\%)}

Uji ketahanan air yaitu uji yang dilakukan untuk mengetahui seberapa besar daya serap bahan tersebut terhadap air dapat dilihat pada Gambar 3 berikut:
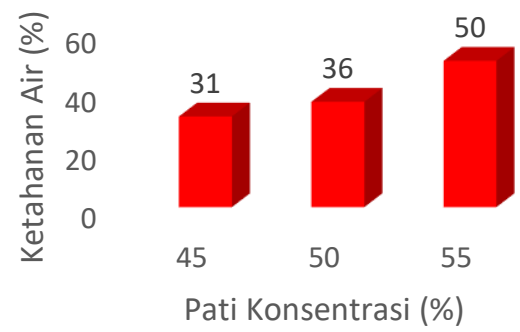

\section{Gambar 3. Pengaruh Penambahan Konsentrasi Pati Terhadap Uji Ketahanan Air Biodegradable}

$$
\text { Hasil analisis terhadap uji }
$$
ketahanan air yang dihasilkan pada Gambar 3 menunjukan ketahanan air pada masingmasing perlakuan yang signifikan. Pada konsentrasi pati $45 \%$ dengan nilai rata-rata sebanyak 31\%, jika merujuk pada SNI biodegradable yaitu sebesar 99\%, maka konsentrasi 45\%, 50\% dan 55\% tidak memnuhi SNI biodegradable. Pada konsentrasi pati $50 \%$ dan $55 \%$ memiliki nilai rata-rata $36 \%$ dan $50 \%$. Perlakuan konsentrasi terbaik pada uji ketahanan air berdasarkan SNI yakni yang paling mendekati nilai SNI pada konsentrasi pati $55 \%$.

Ketahanan air terbaik yang mendekati nilai (SNI) yaitu pada konsentrasi pati $55 \%$ dengan nilai rata-rata $50 \%$. Sedangkan, konsentrasi pati $45 \%$ dan $50 \%$ memiliki nilai rata-rata yaitu $31 \%$ dan $36 \%$ hal ini disebabkan semakin bertambahnya persentasi perbandingan kitosan dan pati menyebakan ketahanan air biodegradable menurun. Konsentrasi pati yang ditambahkan menyebabkan ketahanan air semakin tinggi, hal ini dikarenakan penambahan setiap perlakuan konsentrasi pati ini menyebabkan ikatan biopolimer pati lebih banyak dari ikatan biopolimer kitosan dan gliserol sehingga biopolimer pati yang tidak berikatan ini menyebabkan struktur kimia biodegradable berpori lebih besar dan menyebabkan ketahanan air lebih tinggi.

Menurut Meyer (1985) bahwa sebagian air yang terkandung dalam suatu bahan sukar dihilangkan karena terikat pada molekul-molekul lain melalui ikatan hidrogen yang berenergi besar. semakin banyak molekul pati yang terdapat sebagai pembentuk film yang berarti makin banyak air yang terikat oleh komponen kimia penyusun bahan dan sebaliknya. Hubungan kuat tarik, persen perpanjangan dan ketahanan air terletak pada jumlah biopolimer yang dapat berikatan dengan kitosan dan gliserol. Semakin banyak konsentrasi pati yang ditambahkan maka struktur biopolimer akan semakin rapat dan kaku dan menyebabkan kuat tarik semakin tinggi, sebaliknya persen perpanjangan akan semakin rendah karena kekauan pada film yang memiliki struktur biopolimer yang rapat sehingga perpanjangan film semakin menurun, begitupun dengan 
ketahanan air semakin banyak konsentrasi pati yang ditambahkan maka jumlah biopolimer yang tidak berikatan dengan kitosan gliserol akan semakin banyak dan menyebabkan struktur biopolimer menjadi lebih renggang dan kekuatan menyerap air semakin tinggi.

\section{Uji Biodegradibilitas}

Uji biodegradabilitas dilakukan untuk mengetahui apakah suatu bahan dapat terdegradasi dengan baik di alam. Proses biodegradabilitas dapat terjadi dengan proses hidrolisis (degradasi kimiawi), bakteri/jamur, enzim (degradasi enzimatik), oleh angin dan abrasi (degradasi mekanik), cahaya (fotodegradasi). Biodegradasi adalah perubahan senyawa kimia menjadi komponen yang lebih sederhana melalui bantuan mikroorganisme. Saat degradasi film plastik akan mengalami proses penghancuran alami dapat dilihat pada gambar 4 berikut:

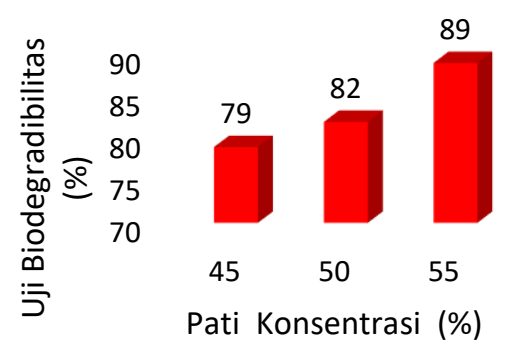

\section{Gambar 4. Pengaruh Penambahan Konsentrasi Pati Terhadap Uji biodegradibilitas Biodegradable}

\section{Uji biodegradasi yang} menggunakan EM4 berdasarkan penelitian yang dilakukan oleh Ummah (2013) bahwa pada EM4 mengandung lactobacillus sp, saccharomyces sp, actinomycetes $\mathrm{sp}$ sehingga membuat biodegradable terdegradasi. Hasil analisis menunjukkan bahwa penambahan konsentrasi pati mempengaruhi degradasi biodegradable secara signifikan $(\mathrm{p}<0.05)$. hal ini disebabkan oleh pati yang digunakan dalam pembuatan biodegradable berikatan dengan gliserol dan kitosan secara seimbang, dan dengan pengadukan secara homogen yang dilakukan selama 25 menit pada suhu $85^{\circ} \mathrm{C}$ sehingga biodegaradable dengan perlakuan pati degaradasi pada hari ke 7. Pada hari ke-7 perlakuan konsentrasi tanpa pati, $45 \%, 50 \%$ dan $55 \%$ mengalami penurunan berat secara signifikan ini menunjukan bahwa biodegaradble sangat mudah terdegradasi.

Biodegradable dapat dikatakan ramah lingkungan jika dapat terdegradasi dengan baik. Analisis degradasi biodegradable dilakukan melalui pengamatan secara visual selama 7 hari. Pada hari pertama biodegradable masih berupa lembaran bening, kemudian pada hari ke-7 biodegradable menjadi berwarna hitam. Perendaman dalam bakteri EM4 selama 7 hari mengakibatkan biodegradable terdekomposisi secara perlahan. Hasil uji biodegradasi ini menunjukkan biodegradable berbahan pati kulit ubi kayu dapat dikatakan sebagai plastik yang ramah lingkungan (biodegradable).

Perlakuan variasi konsentrasi pati menghasilkan tingkat degradasi yang berbeda-beda dari biodegradable. Tingkat degradasi biodegradable tersebut dapat dilihat dari besarnya nilai persen degradasi. Perbandingan nilai persen degradasi dari biodegradable ditunjukan pada gambar 4 yang menunjukkan bahwa biodegradable yang mudah terdegradasi adalah biodegradable dengan penambahan konsentrasi $55 \%$ yang dibuktikan dengan persen degradasi sebesar $89 \%$. Biodegradable dengan penambahan konsentrasi $45 \%$ dan $50 \%$ memiliki persen degradasi paling rendah yaitu sebesar $79 \%$ dan $82 \%$. Hal ini terjadi berkaitan dengan kemampuan biodegradable dalam menyerap larutan bakteri EM4. Semakin banyak konsentrasi pati yang ditambahkan maka biodegradable cenderung semakin 
mudah terdegradasi. Gliserol dan pati memiliki sifat hidrofilik sehingga mempunyai kemampuan untuk mengikat air. Air merupakan media tumbuh bagi sebagian besar bakteri dan mikroba, sehingga kandungan air yang tinggi mengakibatkan bioplastik menjadi lebih mudah terdegradasi.

\section{Simpulan}

Berdasarkan dari data hasil penelitian, maka dapat disimpulkan bahwa penambahan konsentrasi pati kulit ubi kayu (Manihot esculenta) berpengaruh secara signifikan terhadap uji yang meliputi karakteristik kuat tarik, persen perpanjangan, ketahanan air dan biodegradibilitas. Konsentrasi pati yang divariasikan, dihasilkan 45\%, 50\% dan $55 \%$ dengan nilai kuat tarik untuk masingmasing konsentrasi yaitu $25,57 \mathrm{MPa}$, $31,84 \mathrm{MPa}$ dan $73,97 \mathrm{MPa}$. Nilai perpanjangan untuk masing-masing konsentrasi yaitu $125,4 \%, 126,1 \%$ dan $103,9 \%$. Nilai ketahanan air untuk masingmasing konsentrasi yaitu $31 \%, 36 \%$ dan $50 \%$ serta nilai biodegradibilitas mengalami penurunan berat secara signifikan pada konsentrasi $55 \%$ pada hari ke-7 dengan nilai $89 \%$.

\section{DAFTAR PUSTAKA}

Anita, Z., F. 2013. Pengaruh Penambahan Gliserol terhadap Sifat Mekanik Film Plastik dari Pati Kulit Ubi Kayu. Jurnal Teknik Kimia USU, 2 (2):3741.

Arisma. 2017. Pengaruh Penambahan Plasticizer Gliserol terhadap Karakteristik Edible Film dari Pati Talas (Colocasia esculenta L. Schott). Skripsi. Makassar: Universitas Islam Negeri Alauddin.

Arpin. 2017. Study of Making Alternative Biodegradable Plastic Materials from Sweet Potato Starch with Glycerol Plasticizer with Melt Intercalation
Method. Journal of Mechanical Engineering. 06 (2): 80-84.

Badan Pusat Statistik. 2005. Sulawesi Barat dalam Angka. Badan Pusat Statistik, Sulawesi Barat.

Budiardi. 2016. Studi Konversi Pati Ubi Kayu (Cassava Starch) menjadi Glukosa Secara Enzimatik. Jurnal Teknik Kimia. 03(1):7-16.

Coniwanti, A.H., Susilawati., S. Nurdjanah.,\& Putri, S. 2014. Karakteristik Sifat Fisik \& Kimia Ubi Kayu (Manihot Esculenta) Berdasarkan Lokasi Penanaman \& Umur Panen Berbeda. Jurnal Teknologi Hasil. 2(13): 22-30.

Ginting, M.H.S., M.F.R., Tarigan, \& A.M. Singgih, 2015. Effect of Gelatinization Temperature and Chitosan on Mechanical Properties of Bioplastics from Avocado Seed Starch (persea americana mill) with Plasticizer Glycerol. Journal of Engineering And Science. 4 (12) : 3643.

Harsojuwono, B.A. \& I.W.A.S. Muliani, 2017. Biodegradable Plastic Characteristics of Cassava Starch Modified in Variations Temperature and Drying Time. Chemical and Process Engineering Research 49(12) :2225-2913.

Saputro. 2017. Synthesis \& Characterization of Bioplastics from Canosan Pati Canna (Canna Edulis). Journal of Chemistry \& Chemistry Education, 2 (1): 15-27.

Sanjaya, G. L. \& Puspita, L., 2010. The Effect of Addition of Khitsan \& Glycerol Plasticizer on the Characteristics of Biodegradable Plastics from Starch Waste Cassava Bark. Surabaya: Sepuluh November Institute of Technology.

Selpiana 2016. Effect of Addition of Chitosan \& Glycerol on Bioplastic Making from Sugarcane \& Tofu Dregs. Journal of Chemical Engineering, 22 (1): 10-12. 
Setyowati. 2013. Studi Sifat Fisik,Kimia, dan Morfologi pada Kemasan Makanan Berbahan Styrofoam dan LDPE (Low Density Polyethylene). Jurnal Teknik Mesin, 22(3):10-13.

Ummah. 2013. Uji Ketahanan Biodegaradable plastic Berbasis Pati Tepung Biji Durian (Durio Zibethinus Murr) terhadap Air dan Pengukuran Densitasnya. Skripsi Makassar: Universitas Negeri Islam Alauddin.

Uhsnul, F.J., 2017. Pengaruh Penambahan Kitosan terhadap Karakteristik . Bioplastik dari Pati Kulit Kentang. Skripsi Makassar: Universitas Negeri Islam Alauddin.

Winarmo, F.G., 2002. Food and Nutrition Chemistry. Jakarta: PT. Gramedia Main Library. 